\title{
FUNGI IN A LOWER CRETACEOUS TURTLE EGG FROM CHINA: EVIDENCE OF ECOLOGICAL INTERACTIONS
}

\author{
FRANKIE D. JACKSON, ${ }^{*}$ XINGSHENG JIN, ${ }^{2}$ and JAMES G. SCHMITT ${ }^{1}$ \\ ${ }^{1}$ Department of Earth Sciences, Montana State University, Bozeman, Montana, 59717, USA; ${ }^{2}$ Zhejiang Museum of Natural History, Hangzhou 310012, China, and \\ Fukui Prefectural Dinosaur Museum, Katsuyama, Fukui, 911-8601 Japan \\ e-mail: frankiej@montana.edu
}

\begin{abstract}
Fossil fungi and arthropod body parts are present in one of 27 unhatched eggs in a turtle egg clutch from the Lower Cretaceous (Albian) Liangtoutang Formation, Zhejiang Province, China. The fossil fungal structures include branching septate hyphae, conidiophores supporting multiple phialides, and chains of up to five basipetal conidia (asexual spores). The morphology of the fossil fungus is similar to extant taxa within the genus Penicillium (order Eurotiales), making it the first reported intact Early Cretaceous asexual ascomycete and the earliest record of a presumed intact Penicillium. Biomineralization, a physiologic response to calcium-rich microenvironments, occurs in some extant fungi and may have facilitated detailed preservation of the fossil specimen. This rare evidence of fungal-animal association provides clues to clutch-related paleoecological interactions. The fungus-bearing egg occurs on the clutch periphery, whereas adjacent and more distant eggs show no evidence of fungal invasion. We suggest that the fungi were opportunistic contaminants invading after the egg was compromised, and the fungus failed to spread to adjacent eggs prior to burial and fossilization.
\end{abstract}

\section{INTRODUCTION}

Fungi are one of the most taxonomically diverse groups of organisms on Earth, comprising at least 1.5 million species (Hawksworth, 2001). They are also ecologically diverse and play important roles in nutrient cycling and decomposition of plant and animal matter in modern terrestrial environments (Brady and Weil, 2002). Their fossil record coincides with colonization of terrestrial ecosystems by plants during the Ordovician and Silurian (Sherwood-Pike and Gray, 1985; Redecker et al., 2000). Despite this early appearance, fungal structures are rare in the geologic record because of the poor preservation potential of their delicate, filamentous structures called hyphae. As a consequence, their ecological role and interactions with other organisms in ancient environments remain poorly understood. In addition, fossil fungi are primarily associated with plants (e.g., Taylor and Osborn, 1996; Tripathi, 2001; Taylor et al., 2005; van der Ham and Dortangs, 2005; Schmidt et al., 2006), whereas reports of fungal-animal interactions are limited (e.g., White and Taylor, 1989), and few studies discuss possible mechanisms for preservation of fungal structures. Here, we report fossilized fungi discovered in a turtle egg clutch from the Lower Cretaceous Liangtoutang Formation, Zhejiang Province, China. The clutch contains a minimum of 27 eggs, one of which preserves fungal structures and arthropod body parts. This specimen represents the first intact Early Cretaceous asexual ascomycete and possibly the oldest Penicillium (Eurotiomycetes) in the fossil record. We discuss fungal biomineralization as a possible mechanism facilitating exceptional preservation of the fungal structures and the role of fungi as opportunistic contaminants in the Early Cretaceous ecosystem.

* Corresponding author.

Copyright $\odot$ 2009, SEPM (Society for Sedimentary Geology)

\section{STRATIGRAPHIC CONTEXT}

The fossil turtle egg clutch containing the fungi came from the Tiantai Basin in Zhejiang Province, southeastern China (Fig. 1). This Cretaceous basin-fill sequence includes the Qujiang Group, which in ascending order consists of the Tangshang, Liangtoutang, and Chichengshan Formations (Wang et al., 2000). Both the Tangshang $\left({ }^{40} \mathrm{Ar} /{ }^{39} \mathrm{Ar}\right.$ age $\left.=109.2 \mathrm{Ma}\right)$ and Liangtoutang $(\mathrm{K} / \mathrm{Ar}$ ages $=105.9-$ 103.2 Ma) Formations are Lower Cretaceous (Albian) in age (Li et al., 1989; Wang et al., 2000). Wang et al. (2000) considered the Chichengshan Formation as Upper Cretaceous but did not report radiometric dates. In ascending order, lithologic units of the Tangshang Formation include red sandstones and breccia tuff, felsic tuff with andesitic agglomerate and porphyritic dacite, and rhyolite. Purplishred, medium- to thick-bedded calcareous siltstone, muddy siltstone, and some rhyolitic tuffs comprise the overlying Liangtoutang Formation. Finally, the Chichengshan Formation includes purple to red-grey mudflow conglomerates intercalated with argillaceous siltstone (Wang et al., 2000).

Construction workers discovered the fossil turtle egg clutch in the Liangtoutang Formation, exposed near the city of Tiantai (Fig. 1B). The red siltstones of the Liangtoutang Formation primarily record shallow-water lacustrine deposition; however, at this locality the fossil turtle egg clutch truncated ripple cross laminations in a fine-grained, red sandstone with moderately abundant root and burrow traces (Jackson et al., 2008). The clutch contained a minimum of 27 turtle eggs, four of which separated from the sandstone block during excavation (Fig. 2). Identification of the clutch was based on the characteristic microstructure and aragonite composition of the eggshell, which is unique to turtle eggs (Jackson et al., 2008). The eggs are 34 $52 \mathrm{~mm}$ in diameter and occur in three levels within the sandstone, suggesting they were buried in the substrate similar to modern turtle eggs. Most eggs are intact and none contain obvious embryonic remains.

\section{MATERIALS AND METHODS}

Serendipitous discovery of the fossil fungus occurred during demonstration of a new Zeiss Supra VP field-emission microscope (FEM) at the Imaging and Chemical Analysis Laboratory at Montana State University. For a previous study using a scanning electron microscope (SEM), eggshell samples had been removed from 3 of 23 eggs in the egg clutch (ZMNH M8713). The eggshells were broken, mounted on aluminum stubs, coated with $10 \mathrm{~nm}$ of gold, and imaged under the SEM (Jackson et al., 2008). One of these three SEM samples (ES 137) was later used to demonstrate the new FEM; the specimen was imaged at $15 \mathrm{kV}$ and substantially higher magnification $(>24,000 \times)$ than employed in the original study of the eggshell microstructure. Structures identified as fungal hyphae and conidia were then analyzed under a PGT Ge (germanium) energy dispersive X-ray (EDX) detector attached to the FEM. Eggshells from the original eggs in the study (ES 


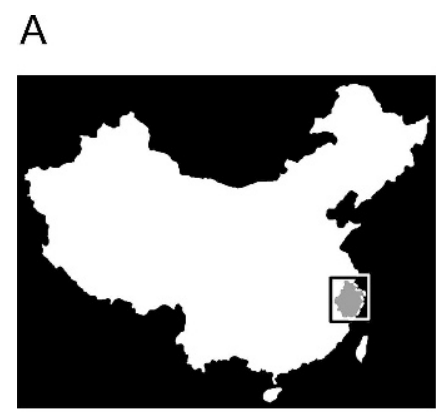

\section{B}

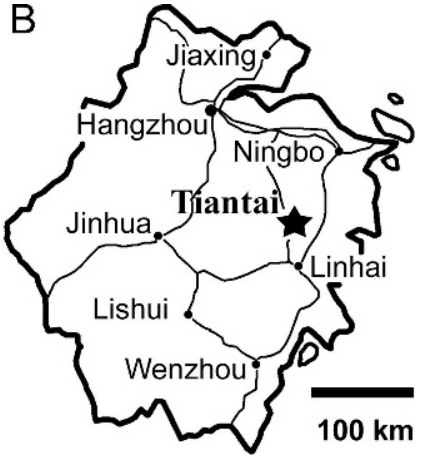

FIGURE 1-Location of study area. A) Map of China indicating location of Zhejiang Province. B) Zhejiang Province showing the city of Tiantai where outcrops containing turtle clutch are exposed.

142, ES 143) and additional eggshells (ES 186-ES 190) from five eggs in the clutch were also examined at similar magnification. For comparison, modern Penicillium was grown on fossil eggshell, dehydrated, coated with $10 \mathrm{~nm}$ of gold, and also analyzed at $15 \mathrm{kV}$ by FEM. The clutch (ZMNH M8713) and all fossil eggshells are housed at the Zhejiang Natural History Museum in Hangzhou (ZMNH), Zhejiang Province, China.

\section{DESCRIPTION OF FOSSIL SPECIMENS}

Field-emission microscope examination of ES 137 revealed that fungi occupied a vacuity in the eggshell interior, possibly a pore (Fig. 3). Quantitative EDX analysis of several spores and hyphae showed no significant carbon and an elemental composition consistent with calcite and hematite replacement during diagenesis (Fig. 4A-B; Table 1). Examination of an adjacent egg and several eggs more distant from ES 137 (Fig. 2) failed to detect the presence of fungi.

The fungal structures preserved within the eggshell interior often include 1.5-3.0 $\mu$ m-wide branching hyphae with septa. These hyphae sometimes display a finely villose surface that is smooth in some areas (Fig. 3A-B). Univerticillate conidiophores (stalks that bear conidia, i.e., asexual spores) are $6 \mu \mathrm{m} \times 18 \mu \mathrm{m}$ and support up to four phialides, a type of bottle-shaped conidiogenesis cell; these are $1.5 \mu \mathrm{m} \times 5.0 \mu \mathrm{m}$ and exhibit a smooth surface (Fig. 3A). Chains of up to five basipetal developing, globose-to-subglobose immature conidia $(2.3 \mu \mathrm{m} \times$ $3.0 \mu \mathrm{m})$ are present on conidiophores, whereas mature conidia are dispersed throughout the fungal material (Fig. 3). The mature conidia exhibit a definitive attachment point consisting of an echinulate (spiny) rim and include a second attachment point at the opposite end, suggesting they are catenulate (in chains). Echinulae (minute spines) are 200-400 nm high by 200-300 nm wide at the base, triangular and blunt at the apex. Smaller $(1.5-2.0 \mu \mathrm{m})$, smooth, globose conidia are also present within the eggshell, primarily attached to phialides as immature asexual spores (Fig. 3A).

Animal body parts occur in close association with the fungus and include segmented appendages with barbed and smooth, tapering hairlike setae that are $1.0 \mu \mathrm{m}$ wide at the base and $20 \mu \mathrm{m}$ long (Fig. 3A). The barbed setae occasionally display fine longitudinally oriented lines. Club-shaped setae with sockets (trichoid sensillum) suggest an arthropod affinity for these structures (M. Ivie, personal communication, 2008).

\section{DISCUSSION}

The Kingdom Fungi consists of at least five phyla: Chytridiomycota, Zygomycota, Glomeromycota, Ascomycota, and Basidiomycota. Nearly all basal terrestrial fungi produce aseptate filaments, whereas

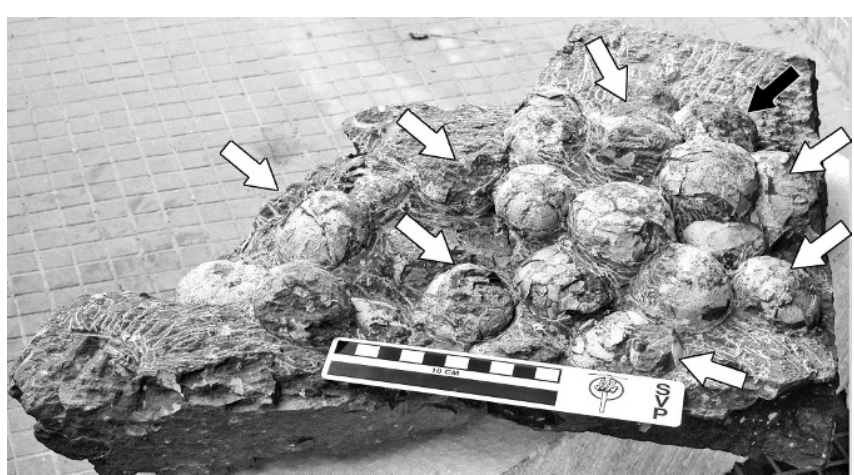

FIGURE 2-Sandstone block containing 23 turtle eggs from the Lower Cretaceous Liangtoutang Formation, China; four additional eggs separated from the clutch during excavation; black arrow indicates location of egg that contains the fungus (ES 137); white arrows show additional eggs examined; scale bar $=10 \mathrm{~cm}$.

more-derived fungi such as basidiomycetes and ascomycetes are characterized by regularly septate filaments (Berbee and Taylor, 1993). The basidiomycetes typically produce sexual spores on specialized, external spore-bearing structures (basidia), whereas the ascomycetes exhibit rows of sexual spores within an elongated cell (ascus). Asexual ascomycetes also have septate hyphae and reproduce typically by conidia and other asexual spores; however, many lack a sexual stage and, therefore, are traditionally grouped into an artificial category (deuteromycetes) defined primarily by what they are not (Kalgutkar and Jansonius, 1993).

Comparison of the Lower Cretaceous fungi found in this investigation to extant fungi allows assignment to the Ascomycota as an asexual form of the Eurotiomycetes (Geiser et al., 2006). The morphology of the fossil fungus is similar to extant taxa within the genus Penicillium, in the order Eurotiales. We base this identification on the brush-like conidiophores, which consist of a stalk and branches bearing phialides that produce chains of basipetal conidia (Fig. 3).

Modern fungal contamination can be ruled out in the case of the Tiantai specimen for several reasons. The fungus and body parts are not located on the egg exterior but were exposed within a vacuity in the eggshell, after the shell was broken to obtain a fresh surface for SEM analysis. Furthermore, these organisms are not present in adjacent or more distant eggs in the clutch. The gold coating (applied immediately after the shell was broken) covers the fungus, indicating that modern Penicillium did not colonize the eggshell between the SEM and FEM examinations. It is also unlikely that these organisms washed into the eggshell at a later geologic time because authigenic calcite and sediment fill the pores that traverse the eggshell. The more plausible explanation is that they entered when nutrients were still available in the egg and prior to this infilling by minerals and sediment.

Finally, EDX analyses of several fossil conidia and hyphae reveal an insignificant amount of carbon present in the samples: $0.09 \%$ and $0.48 \%$, respectively (Figs. 4A-B; Table 1). In contrast, EDX analysis of a conidium from an extant Penicillium (Fig. 5), coated with the same amount of gold $(10 \mathrm{~nm})$, reveals $12.59 \%$ carbon by weight and significantly lower $\mathrm{Ca}(0.77 \%)$ than present in the fossil conidium (Figs. 4 A, C; Table 1). This represents one to two orders of magnitude difference between the modern and fossil specimens. An uncoated conidium of modern Penicillium contains an even greater amount of carbon, $14.07 \%$ by weight. The mineralized fungus exhibits variation in authigenic mineral replacement (i.e., hematite, calcite), which is similar to the fossil turtle eggshell. In the latter, calcite primarily replaces the original aragonite and authigenic hematite represents a relatively minor constituent. Some elements (e.g., Al, Mg, Fe) revealed by XRD analysis of the modern fungus are typically found in trace amounts. The greater percentage of these elements in the extant Penicillium in this study may 

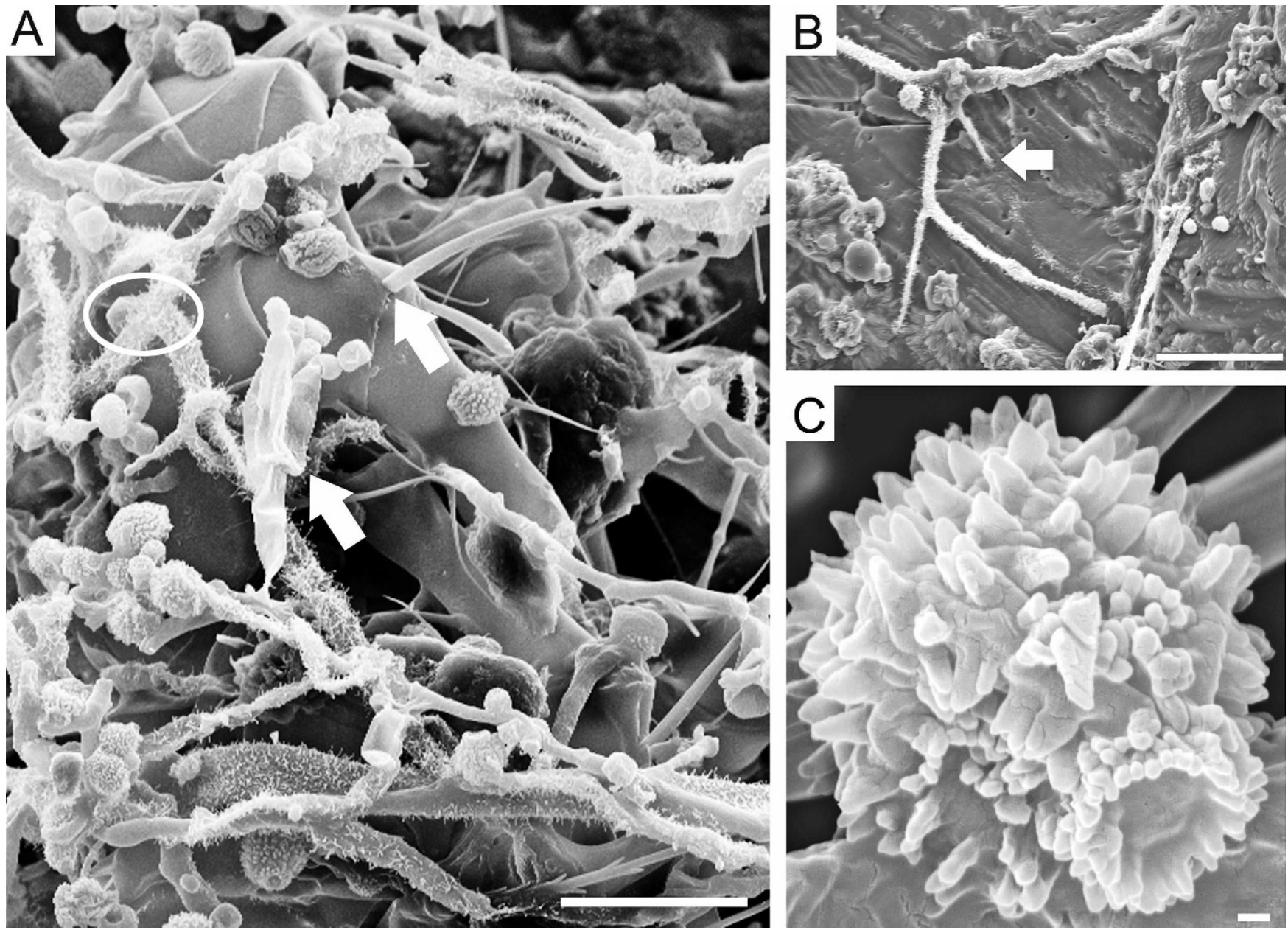

FIGURE 3-Fungi in fossil turtle eggshell. A) Fungal mass with dispersed echinulate mature spores (conidia); lower arrow indicates conidiophore with attached phialides and young conidia in chains; note segmented arthropod body parts in background (upper arrow points to smooth tapering hair-like setae; circle indicates location of EDX analysis (Fig. 4B; Table 1); scale bar $=10 \mu \mathrm{m}$. B) Branching, finely villose fossil hyphae; white arrow indicates point where hypha enters eggshell; scale bar $=20 \mu \mathrm{m}$. C) Echinulate conidium with attachment point; EDX spectrum was collected from the center of the conidium (see Fig. 4A, Table 1); scale bar $=1 \mu \mathrm{m}$.

reflect the presence of clays associated with the fossil eggshell on which the Penicillium was grown.

\section{The Fossil Record of Fungi}

The fossil record of fungi extends back to the Precambrian, but the systematic position of these fossils remains uncertain (Kalgutkar and Jansonius, 2000, and references therein; Butterfield, 2005). Several major groups of fungi, however, were well established by Paleozoic time (Taylor, 1993; Taylor and Taylor, 1997). For example, a phialide characteristic of certain deuteromycetes is known from the Silurian (Sherwood-Pike and Gray, 1985), and the oldest reported asexual and sexual stage of an ascomycete (Taylor et al., 1999) occurs in association with early land plants from the Lower Devonian. Although modern genera of ascomycetes, deuteromycetes, and basidiomycetes appear well established by the Late Cretaceous (Watanabe et al., 1999; Hibbett et al., 2002), the first report of an intact fossil within the Eurotiomycetes, an Aspergillus, comes significantly later, reported from Eocene amber (Thomas and Poinar, 1988). The fungus from the Tiantai Basin, therefore, represents the first intact asexual ascomycete reported from the Early Cretaceous and may represent the earliest record of an intact Penicillium.

The fossil record of fungi primarily documents associations with phototropic organisms such as lichens, wood, and plant roots, or fungi preserved in amber (e.g., Taylor and Osborn, 1996; Watanabe et al., 1999; Tripathi, 2001; Wilkinson, 2003; Taylor et al., 2005; van der
Ham and Dortangs, 2005; Schmidt et al., 2006). In contrast to these fungal-plant associations, the fossil record of fungal-animal interactions consists of fungi associated with coral and marine shell borings and microarthropod fecal pellets from the Silurian (Sherwood-Pike and Gray, 1985), and trichomycetes (ubiquitously associated with arthropods today) that occur with Triassic insect exoskeletons (White and Taylor, 1989). Fungi are also described with plants in dinosaur coprolites from the Upper Cretaceous (Maastrichtian) Lameta Formation of India (Sharma et al., 2005) and co-occur with microbes, algae, and arthropods in Cretaceous and Eocene amber (Taylor, 1990; Schmidt et al., 2006; Poinar and Buckley, 2007). The sample in this study represents the first report of fungi preserved in a fossil turtle egg.

\section{Mechanism for Calcification of Fungal Spores and Hyphae}

The highly detailed fungal structures preserved in the Cretaceous turtle eggshell raise important questions about potential processes responsible for replication of the three-dimensional fungal morphology. Such soft-tissue preservation is often facilitated by precipitation of calcium carbonate or other authigenic minerals, controlled by the distinct geochemical signature of decay-related microenvironments (e.g., Briggs and Kear, 1993; Sagemann et al., 1999; Briggs, 2003). For example, McNamara et al. (2009) showed that geochemical aspects of specific decay microenvironments in a single fossil frog vary with 

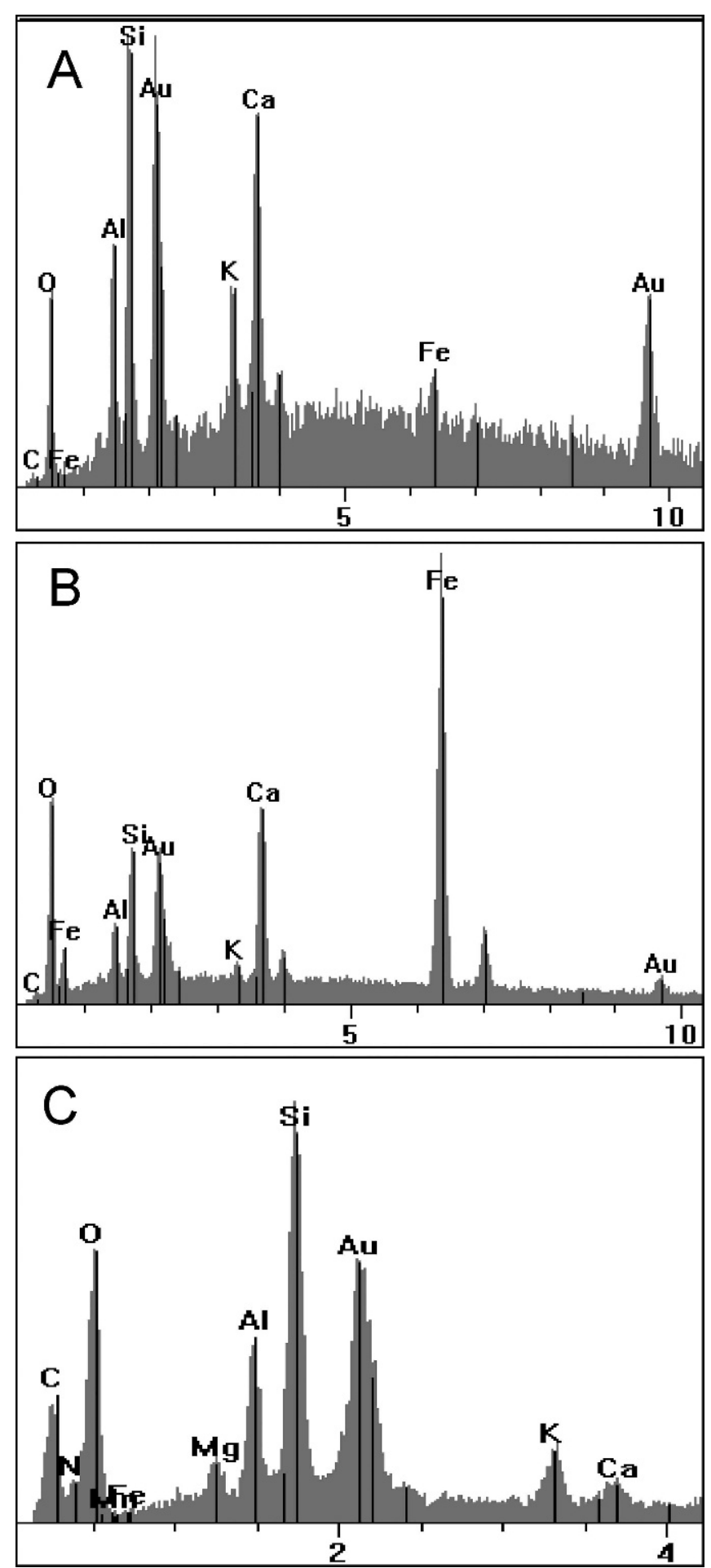

FIGURE 4-Energy dispersive X-ray (EDX) spectra of fossil and modern fungi. A) Fossil conidium shown in Figure $3 \mathrm{C}$; note the absence of significant carbon and elemental composition consistent with calcite. B) Fossil hypha circled in Figure 3A; elemental composition is consistent with hematite. C) Modern Penicillium conidium in Figure 5; note significantly lower calcium and greater carbon compared to fossil specimens; gold peak $(\mathrm{Au})$ in all samples results from coating applied prior to analyses.

anatomical and physiological factors of the living organism (tissue and organ function) and stage of decay. Similarly, physiological processes that drive biomineralization in fungi (including some species of Penicillium) have been recognized for over a century (Verrecchia, 2000, and references therein) and provide a plausible explanation for their own preservation by calcium carbonate precipitation, a process referred to as autolithification.

Several physiological aspects of fungi are pertinent to autolithification, including their (1) capacity for absorption and excretion of substances through all parts of the hyphal wall, (2) need for $\mathrm{Ca}^{2+}$ for hyphal growth, (3) calcium storage potential, and (4) capacity to excrete large quantities of organic acids, particularly oxalic acid (Verrecchia, 2000). The calcium necessary for hyphal growth can be extracted from the surrounding environment, including carbonate rock substrates, sediments (Verrecchia, 1993; Chang and Li, 1998; Stirflinger, 2000), or in the case of modern turtle eggs, from eggshell itself (Phillott and Parmenter, 2006).

In excessively Ca-rich environments, however, calcium ions inhibit enzymatic activity and retard fungal growth. To maximize enzymatic efficiency, fungi precipitate calcium oxalate or calcium carbonate crystals (which are very insoluble) as a mechanism of sequestering calcium outside of the fungal cell wall and decreasing the calcium ion concentration in the immediate environment (Verrecchia, 1993, 2000; Hofmann and Farmer, 2000). Typically, this is sufficient for detoxification of the surrounding substrate.

In well-aerated environments with relatively high $\mathrm{pH}$ and an abundance of sugars, fungi excrete large amounts of oxalic acid that reacts with the calcitic host rock to precipitate polyhydrate calcium oxalate crystals (weddellite) on the fungal hyphae (Verrecchia, 1993). These soon dehydrate to monohydrate calcium oxalate (whewellite), and eventually completely dehydrate to form calcite (Verrecchia, 2000). In dry environments, such as those interpreted for the Tiantai Basin (Wang et al., 2000), some fungi externally mineralize their mycelial strands directly with calcite, rather than calcium oxalate. In these settings, pore solutions can be supersaturated with respect to calcite, favoring rapid $\mathrm{CaCO}_{3}$ precipitation as microcrystalline calcite (micrite).

The calcium oxalate or micritic sheaths precipitated by the fungus outside its cell wall during life may enhance early diagenetic mineralization after death. These mineral precipitates serve as nuclei for subsequent authigenic crystal growth or facilitate replication of fungal morphology by infilling of the fungal structure with mineral crystals following decay of the organism (Latz and Kremer, 1996; Hofmann and Farmer, 2000; Stirflinger, 2000; Schumann et al., 2004). Indeed, calcium carbonate precipitation commonly occurs in voids left by degradation of soft tissue (Martill et al., 1992; Wilby et al., 1996; Hof and Briggs, 1997). Furthermore, in microbial fossilization the size of the structure often corresponds closely to that of the living organism (Hofmann and Farmer, 2000). The capacity of some fungi to remove metals from primary rocks (Latz and Kremer, 1996; Verrecchia, 2000) may also account for hematite replacement of fungal structures in the Chinese turtle eggshell.

Mineralized fungi with similar detailed, three-dimensional morphology are reported from the Jurassic (Mahaney et al., 2004), Oligocene and Miocene (Latz and Kremer, 1996), Eocene (Wilkinson, 2003), and Quaternary-recent (Hofmann and Farmer, 2000). Schumann et al. (2004) noted that open space surrounds the delicate fungal structures present in massive Eocene lava flow units. They argue that the fungus grew in endolithic fashion by dissolving the $\mathrm{CaCO}_{3}$ after the vesicles in the basalts had been filled with carbonate. Although the open space surrounding the fungus in the Cretaceous turtle eggshell may represent a pore, dissolution of the aragonite eggshell by the fungus may also account for this feature. These rare instances of soft-tissue preservation provide important clues to paleoecology and the earliest stages of post-mortem degradation in plant and animalfungal associations.

\section{Early Cretaceous Ecology}

The fossil fungus and arthropod body parts within the turtle eggshell provide rare insight into the interactions of these organisms within the ancient terrestrial ecosystem of the Tiantai Basin. When compared to 
TABLE 1-Elemental composition (\%) of fossil and modern fungi.

\begin{tabular}{llrrrrrrrrrr}
\hline \multicolumn{1}{c}{ Specimen } & Figure & \multicolumn{1}{c}{$\mathrm{C}$} & $\mathrm{O}$ & $\mathrm{Mg}$ & $\mathrm{Al}$ & $\mathrm{Si}$ & $\mathrm{K}$ & $\mathrm{Ca}$ & $\mathrm{Fe}$ & $\mathrm{Au}$ \\
\hline Fossil conidia & 3C,4A & 0.09 & 10.34 & 0.00 & 5.52 & 9.82 & 4.59 & 13.90 & 8.39 & 47.36 & 100 \\
Fossil hyphae & 3A, 4B & 0.48 & 9.94 & 0.00 & 1.59 & 2.93 & 0.49 & 7.56 & 61.06 & 15.94 & 100 \\
Modern Penicillium conidia & 4C, 5 & 12.59 & 52.07 & 1.24 & 3.41 & 7.84 & 1.37 & 0.77 & 2.21 & 16.51 & 100 \\
\hline
\end{tabular}

eggs of modern turtle species, the large egg size, sparse pores, and eggshell microstructure suggest that the eggs were those of a largebodied terrestrial turtle; furthermore, they closely resemble those of modern tortoises in the genus Chelonoidis (Jackson et al., 2008). The unhatched condition of most eggs and apparent absence of embryonic remains suggest that ZMNH M8713 represents a failed clutch.

Fungi in modern ecosystems are ecologically diverse and important as mutualists, parasites, and saprotrophs. As heterotrophs, their association with a carbon and energy source (usually in the form of living or dead organisms) is a requirement for survival. Fungi are ubiquitous in soil and Penicillium and Aspergillus are commonly found in modern turtle nests (Phillott and Parmenter, 2006; Elshafie et al., 2007), often in association with arthropods (Madden et al., 2008). For example, Phillott and Parmenter (2006) report fungi and other mycobiota on $91 \%$ of unhatched eggs in sea-turtle nests in Australia. Repeated use of turtle nesting sites also contributes to higher organic material in the nesting locality than present in the surrounding sediments, thereby providing abundant nutrients for microorganisms (Elshafie et al., 2007). In addition, the presence of fungi and arthropods increases substantially after egg laying (Madden et al., 2008).

Several recent hypotheses relate egg failure in some extant turtle species to the presence of fungi. Putative factors include fungal blockage of pores that diminishes respiratory capacity, penetration of the eggshell and invasion of embryonic tissue, production of mycotoxins, reduction of shell calcium content, and/or enzymatic degradation of shells (Solomon and Baird, 1980; Elshafie et al., 2004, 2007; Phillott and Parmenter, 2006). Antifungal properties of egg albumin and the original mucus layer that covers the eggs after

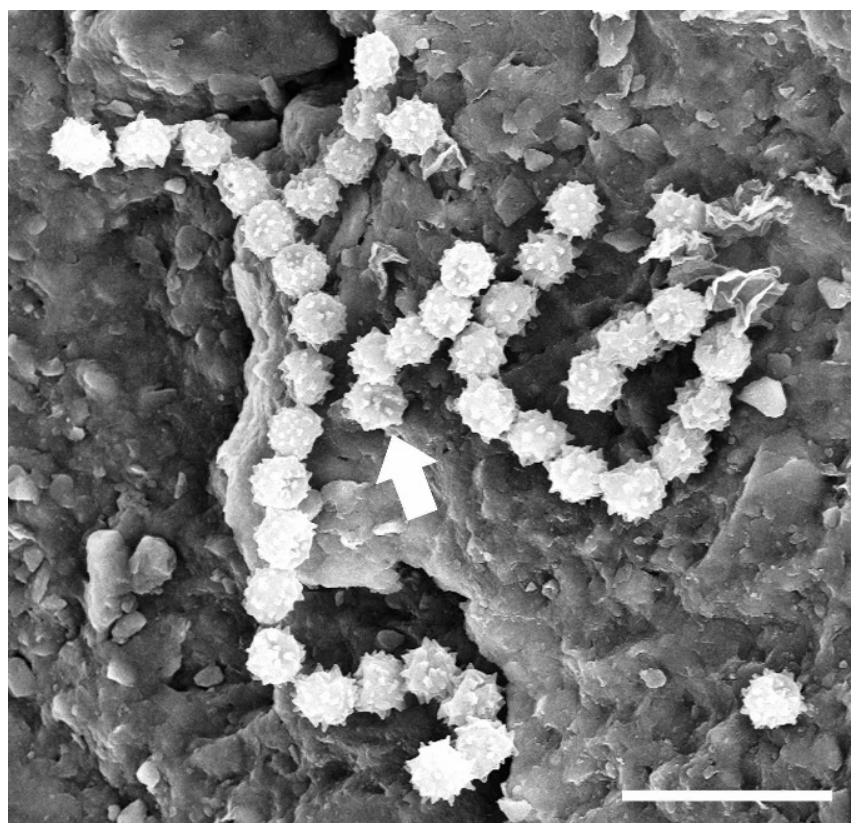

FIGURE 5-Dehydrated conidia of extant Penicillium with fossil eggshell in background; specimen coated with $10 \mathrm{~nm}$ of gold; white arrow points to conidium analyzed by EDX; scale bar $=10 \mu \mathrm{m}$. oviposition, however, also play a role in deterring colonization. Research on modern turtle eggs has sought to determine whether fungi invading turtle eggs are opportunistic contaminants that enter after the egg is compromised or the fungi are initial pathogenic invaders (Solomon and Baird, 1980, Phillott and Parmenter, 2001; Elshafie et al., 2004, 2007). Phillott and Parmenter (2001), for example, argue that fungi are opportunistic contaminants and invasion of green and loggerhead turtle clutches typically begins from a nonviable egg at the top or periphery of the clutch no sooner than a week after observed egg mortality. The fungus then spreads to adjacent eggs at the rate of $1-$ 2 eggs per day, and the entire egg mass is overrun within 10-14 days of its first appearance.

Similar to the observations of Phillott and Parmenter (2001) on modern nests, the fossil egg that contains the fungus and arthropod body parts (ES 137) occurs on the periphery of the clutch, whereas an adjacent egg and several more distant eggs exhibit no evidence of invasion. Although definitive evidence is lacking, we suggest the following scenario: fungal invasion began with a single egg compromised by developmental abnormalities, cracks, or other defects. Effective egg defenses, however, may have prevented further spread of the fungus to adjacent eggs prior to the clutch demise. Finally, extraneous circumstances (e.g., flooding, desiccation due to prolonged drought) terminated embryonic development in the remaining eggs before ossification of skeletal remains, accounting for the absence of embryonic remains and unhatched condition of eggs within the clutch

\section{CONCLUSIONS}

The fungus present in a fossil turtle egg clutch from the Lower Cretaceous (Albian) Liangtoutang Formation, Zhejiang Province, China, represents the first such association reported in the fossil record. The exceptionally well-preserved fungal structures include hyphae and chains of asexual spores (conidia) on supporting structures Immature conidia occur primarily in chains, whereas mature echinulate conidia are more dispersed within the eggshell. Comparison to extant taxa places the fungus in the Ascomycota as an asexual state of Penicillium or a similar genus, thereby representing the first intact asexual ascomycete reported from the Early Cretaceous and possibly the oldest intact Penicillium in the fossil record. Detailed preservation of the fungal structures may have resulted from fungal biomineralization, a process by which excreted calcium forms calcium oxalate or micrite external to the cell wall, thereby facilitating mineralization of the structures. This specimen provides rare insight into fungal-animal interactions in the fossil record. Only one egg on the periphery of the clutch contains fungi, whereas eggs more distant to this specimen show no evidence of fungal invasion prior to clutch demise. Finally, although SEM imaging represents a standard analytical technique in the study of fossil eggshells, higher magnification may provide additional evidence of fungal selective pressure on animal evolution in ancient terrestrial communities.

\section{ACKNOWLEDGMENTS}

We thank C. Cripps for describing the fungi, M. Ivie for identification of the arthropod, and Y. Sheng for fossil preparation. Funding for this project was provided to XJ by the Department of 
Culture and Land Resources, Zhejiang Province, and to FJ by the College of Letters and Science, Montana State University. We thank R. Avci for use of the Imaging and Chemical Analysis Laboratory (ICAL) at Montana State University, and N. Equall, E. Williams, and M. Bechberger for technical support, B. Jackson and two anonymous reviewers for editorial comments and helpful suggestions that improved the manuscript.

\section{REFERENCES}

Berbee, M.L., and TAYlor, J.W., 1993, Dating the evolutionary radiations of the true fungi: Canadian Journal of Botany, v. 71, p. 1114-1127.

Brady, N.C., and WeIL, R.R., 2002, The Nature and Properties of Soils: Prentice Hall, New Jersey, p. 960.

BRIGGS, D.E.G., 2003, The role of decay and mineralization in the preservation of soft-bodied fossils: Annual Review of Earth and Planetary Sciences, v. 31, p. 275 301.

Briggs, D.E.G., and KeAR, A.J., 1993, Fossilization of soft tissue in the laboratory: Science, v. 259, p. 1439-1442.

Butterfield, N.J., 2005, Probable Proterozoic fungi: Paleobiology, v. 31, p. 165-182.

Chang, T.T., and Li, C.Y., 1998, Weathering of limestone, marble, and calcium phosphate by ectomycorrhizal fungi and associated microorganisms: Taiwan Journal of Forestry Science, v. 13, p. 85-90.

Elshafie, A.E., Ba-Omar, T.A., Al-Bahry, S.N., Mahmoud, I.Y., Al-Kindi, A.Y., and Al-Amri, I., 2004, Localization of fungal hyphae in the eggshells of the green sea turtle Chelonia mydas from Ras Al-Hadd Reserve, Oman: Microscopy and Microanalysis, v. 10, p. 1536-1537.

Elshafie, A.E., Al-Bahry, S.N., Alkindi, A.Y., Ba-Omar, T., and Mahmoud, I., 2007, Mycoflora and aflatoxins in soil, eggshells and failed eggs of Chelonia mydas at Ras Al-Jinz, Oman: Chelonian Conservation and Biology, v. 6, p. 267-270.

Geiser D.M., Gueidan, C., Miadlikowska, J., Lutzoni, F., Kauff, F., Hofstetter, V., and Fraker, E., 2006, Eurotiomycetes: Eurotiomycetidae and Chaetothyriomycetidae: Mycologia, v. 98, p. 1053-1064.

Hawksworth, D.L., 2001, The magnitude of fungal diversity: The 1.5 million species estimate revisited: Mycological Research, v. 105, p. 1422-1432.

Hibbett, D.S., Grimaldi, D., and Donoghue, M.J., 2002, Cretaceous mushrooms in amber: Nature, v. 377, p. 487.

Hof, C.H.J., and Briggs, D.E.G., 1997, Decay and mineralization of mantis shrimps (Stomatopoda: Crustacea): A key to their fossil record: PALAIOS, v. 12, p. 420 438.

Hofmann, B.A., and FARmer, J.D., 2000, Filamentous fabrics in low-temperature mineral assemblages: Are they fossil biomarkers? Implications for the search for a subsurface fossil record on the early Earth and Mars: Planetary and Space Science, v. 48 , p. $1077-1086$.

Jackson, F.D., Jin, X., Varricchio, D.J., Azuma, Y., and Jiang, Y., 2008, The first in situ turtle clutch from the Cretaceous Tiantai Basin, Zhejiang Province, China: Journal of Vertebrate Paleontology, v. 28, p. 319-325.

KalgutKar, M., and Jansonius, J., 1993, Synopsis fossil fungal spores: Microbial Ecology, v. 25, p. 305-319.

KalgutKar, M., and Jansonius, J., 2000, Redescription of some of some fossil fungal spores: Palynology, v. 24, p. 37-47, doi: 10.2113/0240037.

Kolo, K., and Claeys, P., 2005, In vitro formation of Ca-oxalates and the mineral glushinskite by fungal interaction with carbonate substrates and seawater: Biogeosciences, v. 2, p. 277-293.

Latz, W., and Kremer P., 1996, Fossile Schimmelpilze im Gestein: Mikrokosmos, v. 85 , p. $229-232$.

LI, K., SHen, J., and WANG, X., 1989, Isotopic geochronology of Mesozoic terrestrial volcanic rocks in the Zhe-jiang-Fujian-Jiangxi area: Journal of Stratigraphy, v. 13, p. 1-13.

Madden, D., Ballestero, J., Calvo, C., Carlson, R., Christians, E., and Madden E., 2008, Sea turtle nesting as a process influencing a sandy beach ecosystem: Biotropica, v. 40, p. 758-765, doi: 10.1111/j.1744-7429.2008.00435.x.

Mahaney, W.C., Milner, M.W., Netoff, D.I., Malloch, D., Dohm, J.M., Baker, V.R., Miyamoto, H., Hare, T.M., and Komatsu, G., 2004, Ancient wet aeolian environments on Earth: Clues to presence of fossil/live microorganisms on Mars: Icarus, v. 193, p. 39-53, doi:10.1016/j.icarus.2004.04.014.

Martill, D. M., Wilby, P.R., and Williams, N., 1992, Elemental mapping: A technique for investigating delicate phosphatised fossil soft-tissues: Palaeontology, v. 35, p. $869-874$.

McNamara, M.E., Orr, P.J., Kearns, S.L., Alcala, L., Anadon, P., and Molla, E.P., 2009, Soft-tissue preservation in Miocene frogs from Libros, Spain: Insights into the genesis of decay microenvironments: PALAIOS, v. 24, p. 104-117.
Phillott, A.D., and Parmenter, C.J., 2001, The distribution of failed eggs and the appearance of fungi in artificial nests of green (Chelonia mydas) and loggerhead (Caretta caretta) sea turtles: Australian Journal of Zoology, v. 49, 713-718.

Phillott, A.D., and Parmenter, C.J., 2006, The ultrastructure of sea turtle eggshell does not contribute to interspecies variation in fungal invasion of the egg: Canadian Journal of Zoology, v. 84, 1339-1344.

Poinar, G.O., JR., and Buckley, R., 2007, Evidence of mycoparasitism and hypermycoparasitism in Early Cretaceous amber: Mycological Research, v. 111, p. 503-506.

Redecker, D., Kodner, R., and Graham, L.E., 2000, Glomalean fungi from the Ordovician: Science, v. 289, p. 1920-1921.

Retallack, G., 2001, Soils of the Past: Blackwell Science, Osney Mead, Oxford, $404 \mathrm{p}$.

Sagemann, J., Bale, S.J., Briggs, D.E.G., and Parkes, R.J., 1999, Controls on the formation of authigenic minerals in association with decaying organic matter: An experimental approach: Geochimica et Cosmochimica Acta, v. 63, p. 1083-1095.

Schmidt, A.R., Ragazzi, E., Coppellotti, O., and Roghi, G., 2006, A microworld in Triassic amber: Nature, v. 444, p. 835.

Schumann, G., Manz, W., Reitner, J., and Lustrino, M., 2004, Ancient fungal life in North Pacific Eocene oceanic crust: Geomicrobiology Journal, v. 21, p. 241-246.

Sharma, N., Kar, R.K., Agarwal, A., and Ratan, K., 2005, Fungi in dinosaurian (Isisaurus) coprolites from the Lameta Formation (Maastrichtian) and its reflection on food habit and environment: Micropaleontology, v. 51, p. 73-82.

Sherwood-Pike, M.A., and Gray, J. 1985, Silurian fungal remains: Probable records of the Class Ascomycetes: Lethaia, v. 18, p. 1-20.

Solomon, S. E., and Baird, T., 1980, The effect of fungal penetration on the eggshell on the green turtle, in Brederoo, P., and de Priester, W., eds., Proceedings of the Seventh European Congress on Electron Microscopy: The Hague, Netherlands, p. $434-435$.

Stirflinger, K., 2000, Fungi as geologic agents: Geomicrobiology Journal, v. 17, p. 97-124.

TAYLOR, T.N., 1990, Fungal associations in the terrestrial paleoecosystem: Trends in Ecology and Evolution, v. 5, p. 21-25.

Taylor, T.N., 1993, Fungi, in Benton, M.J., ed., The Fossil Record, v. 2: Chapman and Hall, London, p. 9-13.

Taylor, T.N., and Osborn, J.M., 1996. The importance of fungi in shaping the paleoecosystem: Review of Palaeobotany and Palynology, v. 90, p. 249-262.

TAYLOR, T.N., and TAYLOR, E.L., 1997, The distribution and interactions of some Paleozoic fungi: Review of Palaeobotany and Palynology, v. 95, p. 83-94.

TAylor, T.N., Hass, H., and KerP, H., 1999, The oldest fossil ascomycetes: Nature, v. 399, p. 648

Taylor, T.N., Remy, W., Hass, H., and Kerp, H., 2005, Fossil arbuscular mycorrhizae from the Early Devonian: Mycologia, v. 87, p. 560-573.

Thomas, G.M., and Poinar, JR., G.O., 1988, A fossil Aspergillus from Eocene Dominican amber: Journal of Paleontology, v. 62, p.141-143.

Tripathi A., 2001, Fungal remains from Early Cretaceous Intertrappean Beds of Rajmahal Formation in Rajmahal Basin, India: Cretaceous Research, v. 22 , p. $565-574$.

van DeR Ham, R.W.J. M., and Dortangs, R.W., 2005, Structurally preserved ascomycetous fungi from the Maastrichtian type area (NE Belgium): Review of Paleobotany and Palynology, v. 136, p. 48-62.

VerrecChiA, E. P., 1993, Role of calcium oxalate biomineralization by fungi in the formation of calcretes: A case study from Nazareth, Israel: Journal of Sedimentary Petrology, v. 63, p. 1000-1006.

Verrecchia, E. P., 2000, Fungi and sediments, in Riding, R., and Awramik, S.M., eds., Microbial Sediments: Springer-Verlag, p. 68-75.

Wang, Y., JiAnG, Y., and Chen, K., 2000, The study of dinosaur fossil and Late Cretaceous basin of Tiantai in Zhejiang: Unpublished file report of the Hydrology and Engineering Geological Brigade of Zhejiang Province and the Chinese Academy of Geological Sciences, available from the library of the Land and Resources Department of Zhejiang Province, China.

Watanabe, K., Nishida, H. and Kobayashi, T., 1999, Cretaceous deuteromycetes on a cycadeoidalean bisexual cone: International Journal of Plant Science, v. 160, p. $435-443$.

White, J.F., JR., and TAYLOR, T.N., 1989, A trichomycete-like fossil from the Triassic of Antarctica: Mycologia, v. 81, p. 643-646.

Wilby, P.R., Briggs, D.E.G., and Riou, B. 1996, Mineralization of soft-bodied invertebrates in a Jurassic metalliferous deposit: Geology, v. 24, p. 847-850.

Wilkinson, H. P., 2003, Fossil actinomycete filaments and fungal hyphae in dicotyledonous wood from the Eocene London Clay, Isle-of-Sheppey, Kent, England: Botanical Journal of the Linnean Society, v. 142, p. 283-394.

ACCEPTED AUGUST 16, 2009 